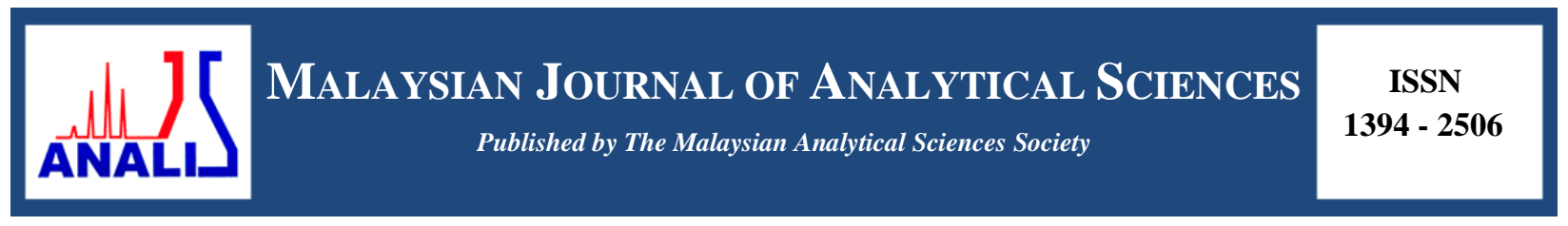

\title{
CELLULOSE NANOCRYSTALS WITH ENHANCED THERMAL STABILITY REINFORCED THERMOPLASTIC POLYURETHANE
}

\author{
(Nanokristal Selulosa Dengan Ketahanan Haba Yang Tinggi Berasaskan Poliuretina \\ Termoplastik) \\ Khairatun Najwa Mohd Amin ${ }^{1 *}$, Pratheep Kumar Annamalai², Darren Martin² \\ ${ }^{1}$ Faculty of Chemical and Natural Resources Engineering, \\ Universiti Malaysia Pahang, Lebuhraya Tun Razak, 26300 Gambang, Kuantan, Pahang, Malaysia \\ ${ }^{2}$ Australian Institute for Bioengineering and Nanotechnology (AIBN), Corner College and Cooper Rds (Bldg 75), \\ The University of Queensland, Brisbane QLD 4072 Australia \\ *Corresponding author: knajwa@ump.du.my
}

Received: 28 November 2016; Accepted: 5 February 2017

\begin{abstract}
Melt compounding processing approach for incorporating cellulose nanocrystals (CNC) into thermoplastic polyurethane (TPU) has not well been explored. This is primarily due to the poor thermal stability and dispersibility of CNCs. As they are typically obtained from sulphuric acid hydrolysis, they give rise to degradation and discolouration of the extruded nanocomposites. The investigation of this research demonstrates sulphuric acid hydrolysis (CNC-S), phosphoric acid hydrolysis (CNC-P) and a novel non-hydrolytic high energy bead milling method (CNC-MC) into a polyether based thermoplastic polyurethane via melt compounding using twin screw extruder. The TPU film incorporated with CNC-S obviously shows the sign of CNC degradation where TPU film was changed to brown colour. The tensile strength of TPU reinforced with CNC-S, CNC-P and CNC-MC shows $18 \%, 16 \%$ and $14 \%$ of improvement at CNC loading of 0 to $1 \mathrm{wt} . \%$ upon host polymer. CNCs isolated via mild acid hydrolysis and mechanical milling methods, can be easily processed via large scale melt-processing techniques for reinforcing thermoplastic polyurethane without affecting their physical appearance and elastic properties.
\end{abstract}

Keywords: cellulose nanocrystals, thermoplastic polyurethane, nanocomposites

\section{Abstrak}

Kajian mengenai penggunaan nanokristal selulosa (CNC) di dalam termoplastik poliuritena (TPU) amat jarang diterokai. Ini adalah kerana CNC mempunyai ketahanan haba yang rendah. CNC yang dihasilkan melalui proses hidrolisis asid sulfurik mudah terdegradasi apabila digabungkan dengan polimer yang melalui proses meramu pencairan umumnya menggunakan suhu pemprosesan yang tinggi. Kajian ini menggunakan CNC yang dihasilkan daripada hidrolisis asid sulfurik (CNC-S), asid fosforik (CNC-P) dan kaedah novel pengisaran manik (CNC-MC) ke dalam poliuretana termoplastik berasaskan berasas polieter melalui proses meramu pencairan. Filem TPU yang digabungkan dengan CNC-S jelas menunjukkan tanda degradasi CNC apabila filem TPU bertukar warna kepada coklat. Kekuatan tegangan TPU diperkukuhkan dengan CNC-S, CNC-P dan CNC-MC menunjukkan $18 \%, 16 \%$ dan $14 \%$ peningkatan pada muatan CNC 0-1 wt.\% di dalam komposit. CNC yang dihasilkan melalui hidrolisis asid berkekuatan sederhana dan melalui kaedah mekanikal boleh diproses melalui teknik meramu pencairan yang berskala besar dan mampu meningkatkan kekuatan poliuretana termoplastik tanpa menjejaskan penampilan fizikal mereka dan sifat elastiknya.

Kata kunci: nanokristal selulosa, poliuritena termoplastik, nanokomposit 


\section{Khairatun Najwa et al: CELLULOSE NANOCRYSTALS WITH ENHANCED THERMAL STABILITY REINFORCED THERMOPLASTIC POLYURETHANE}

\section{Introduction}

Thermoplastic polyurethane (TPU) is a versatile material which has both thermoplastic and elastomeric properties with unique attributes, for instance, melt-process ability, recyclability and easy to mould [1]. One of the methods to improve the properties of TPU is by using reinforcing filler. Recently nanoscale fillers such as clay, carbon nanotubes, metal and metal oxides have been demonstrated to remarkably enhance the thermal, physical and mechanical properties of TPU within very low loading [2-4]. Recently cellulose nanocrystal (CNC) has gained high attention as reinforcing filler due to its key attributes such as very high specific mechanical properties of individual nanocrystals and renewability. Moreover, $\mathrm{CNC}$ reinforced polymer nanocomposites can retain the transparency of the polymer matrix [5]. With polyurethanes and different types of nanocellulose particles, remarkable reinforcements have been demonstrated. Specifically at a low volume fraction of CNC, TPU nanocomposites has demonstrated an extraordinary increase in tensile strength without compromising the tensile strain and stiffness of the material [6]. However, their processing involves solvent based methods. Conventional method like solvent casting poses a challenge in terms of production speed and environmental issue due to the high solvent usage [7]. Thus, for TPU industrial scale production, classical melt-processing methods such as compounding, reactive extrusion and moulding are preferred. Melt compounding method which has been explored with other thermoplastics whose fusion temperatures are below $170^{\circ} \mathrm{C}$ such as poly lactic acid [8] and polyethylene [9], is however limited due to the poor thermal stability, dispersibility of CNCs and degradation in optical transparency of the host for most of the thermoplastics whose processing temperatures are above $170{ }^{\circ} \mathrm{C}$.

Hence, this work focuses on the processing of TPU nanocomposites reinforced with three types of CNCs which were obtained via sulphuric acid hydrolysis (CNC-S), and phosphoric acid hydrolysis (CNC-P) and acid-free high energy bead milling (CNC-MC), via a classical melt compounding method using an intermediate scale twin screw extruder. Their processing and properties enhancement are compared with the nanocomposites processed by solvent casting method.

\section{Materials}

\section{Materials and Methods}

Cellulose source used was Whatman filter paper (Advantec) and commercial microcrystalline cellulose (Avicel PH101). Sulphuric acid $\left(\mathrm{H}_{2} \mathrm{SO}_{4}, 98 \%\right)$ and ortho-phosphoric acid $\left(\mathrm{H}_{3} \mathrm{PO}_{4}, 85 \%\right)$ from Merck Australia was used in for acid the hydrolysis process. The TPU grade selected, Texin 990, was purchased from Bayer Materials Science. This grade was specifically selected because it represents one of the highest selling aromatic polyether grades and is employed in a multitude of applications. Dimethylformamide (DMF) was purchased from Merck and used for solvent casting.

\section{Isolation of cellulose nanocrystals: Acid hydrolysis method}

The isolation process using sulphuric acid was adapted from Capadona et al. [10] with some modifications. The solid to liquid ratio for this isolation process was 1:75. Filter paper was blended with deionised water. The sulphuric acid was added slowly under vigorous mechanical stirring to the cooled filter paper until the final solution reached an acid concentration of $32 \%$. Since the acid hydrolysis process is exothermic, while adding acid, ice bath is used to keep the temperature below $20{ }^{\circ} \mathrm{C}$. After the acid addition is complete the reaction is set at $50{ }^{\circ} \mathrm{C}$ or higher for a stipulated time. The mixture was then heated to $50{ }^{\circ} \mathrm{C}$ for 3.5 hours. The cellulose suspension was cooled to room temperature and was subsequently centrifuged four to five times at $4750 \mathrm{rpm}$ until it became turbid. The cellulose suspension was then dialyses against deionised water until the suspension reached the neutral state. Then the cellulose suspension was ultrasonicated using high intensity ultrasonication (QSonica ultrasonicator) for 30 minutes. Finally, the cellulose suspension was lyophilised using liquid nitrogen and was vacuum freeze dried. The CNC obtained was denoted as CNC-S. Meanwhile, acid hydrolysis of cellulose using $\mathrm{H}_{3} \mathrm{PO}_{4}$ was adapted from Camarero et al. [11], with slight modification, and generally the procedure is very similar to $\mathrm{H}_{2} \mathrm{SO}_{4}$ hydrolysis. This $\mathrm{CNC}$ is denoted as CNC-P.

\section{High energy bead milling method}

Isolation of $\mathrm{CNC}$ via high energy bead milling (HEBM) was carried out based on the work of Amin et al. [12]. The cellulose source used in this process was microcrystalline cellulose (MCC). Various concentrations of MCC were dispersed in deionised water overnight. Then the dispersion was milled using a laboratory agitator bead mill 
(Labstar, Netzsch, Germany). Using various milling times, $0.4 \mathrm{~mm}$ of zirconium beads were used to mill the cellulose dispersion at $1000 \mathrm{rpm}$ in a batch process mode. Finally, the resulting suspensions obtained were freeze dried.

\section{Processing of nanocomposites}

In these nanocomposites, CNC loading levels were $0.5,1$, and 5 wt.\% respectively. In melt compounding method, initially CNC and PU resin were mixed physically. TPU nanocomposites reinforced with three types of CNCs were processed by melt-compounding using a ThermoHaake PolyLab twin-screw extruder. The extrudates were pelletised and compression moulded.

In solvent casting process, TPU resin and CNC were individually dissolved in DMF. $0.5 \mathrm{wt} . \%$ of CNC in TPU was prepared by mixing the desired amounts of CNC and TPU solution in DMF. The mixture was stirred vigorously for 1 hour at room temperature. The mixture was then sonicated for 2 minutes at $20 \mathrm{kHz}$. Subsequently, further stirring was undertaken after the sonication process and immediately cast onto a Teflon petri dish. The films were dried under nitrogen purged for 24 hours and subsequently annealed in a vacuum condition at $80{ }^{\circ} \mathrm{C}$ for 12 hours. TPU nanocomposites prepared by solvent casting were denoted as SC-TPU/CNC $X$ where $X$ represents the volume fraction of CNC. TPU nanocomposites processed via the melt compounding process were denoted as MCTPU/CNC $X$.

\section{Characterisation and mechanical testing}

The morphology and thermal stability of CNCs were characterised by transmission electron microscopy (TEM) and thermogravimetric analysis (TGA). TGA measurements were carried out on a Mettler Toledo DSC/TGA Star ${ }^{\mathrm{e}}$ system using aluminum crucible standard $40 \mu \mathrm{L}$. The samples were heated in a nitrogen atmosphere. The samples were first heated from room temperature to $110^{\circ} \mathrm{C}$, at a heating rate of $10^{\circ} \mathrm{C} / \mathrm{min}$, isothermally held for 10 minutes and further heated to $500{ }^{\circ} \mathrm{C}$ at a heating rate $5{ }^{\circ} \mathrm{C} / \mathrm{min}$.

The mechanical properties of the composites were measured at room temperature on an Instron model 5543 universal testing machine equipped with a $500 \mathrm{~N}$ load cell. The tensile and hysteresis tests were cut into dumbbell shapes according to ASTM d-638-M-3. The tests were performed with a gauge length of $14 \mathrm{~mm}$ and crosshead speed of $50 \mathrm{~mm} / \mathrm{min}$ and pneumatic grips were employed to prevent slippage.

\section{Cellulose Nanocrystals (CNC)}

\section{Results and Discussion}

Figure 1 shows the transmission electron micrographs (a-b) and thermograms (d) of the CNCs obtained via hydrolysis using sulphuric acid (CNC-S), phosphoric acid (CNC-P) and mechanical method (CNC-MC). The dimensions of CNCs were measured from at least 10 particles using ImageJ analytical software. From Figure 1a-c, the 'rod-like' shape CNC can be seen clearly with an average aspect ratio of 13, 10 and 25, for CNC-S, CNC-P and CNC-MC respectively. The HEBM process is more environmentally friendly than the acid hydrolysis methods as it was produced without using any acids, as well as being a more economically viable and scalable approach to produce $\mathrm{CNC}$.

The thermal stability of CNC was determined using TGA and the associated thermograms are shown in Figure 1 (d). It can be clearly seen that CNC-S have the lowest onset degradation temperature $\left(\mathrm{T}_{\text {onset }}\right)$ noted at $200{ }^{\circ} \mathrm{C}$ as

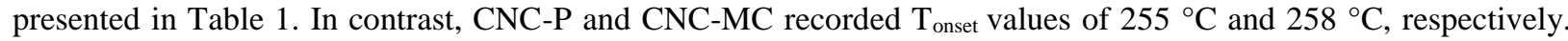
Despite the well-known advantages of $\mathrm{CNC}$ isolated via sulphuric acid hydrolysis in terms of stable aqueous colloidal stability, which is due to the negative sulphate group introduced into the surface of CNC, this method leads to poor thermal stability. The sulphate groups formed are known to promote dehydration reactions and act as flame retardants, but this characteristic also gives rise to a low nanocellulose thermal stability [13,14]. 

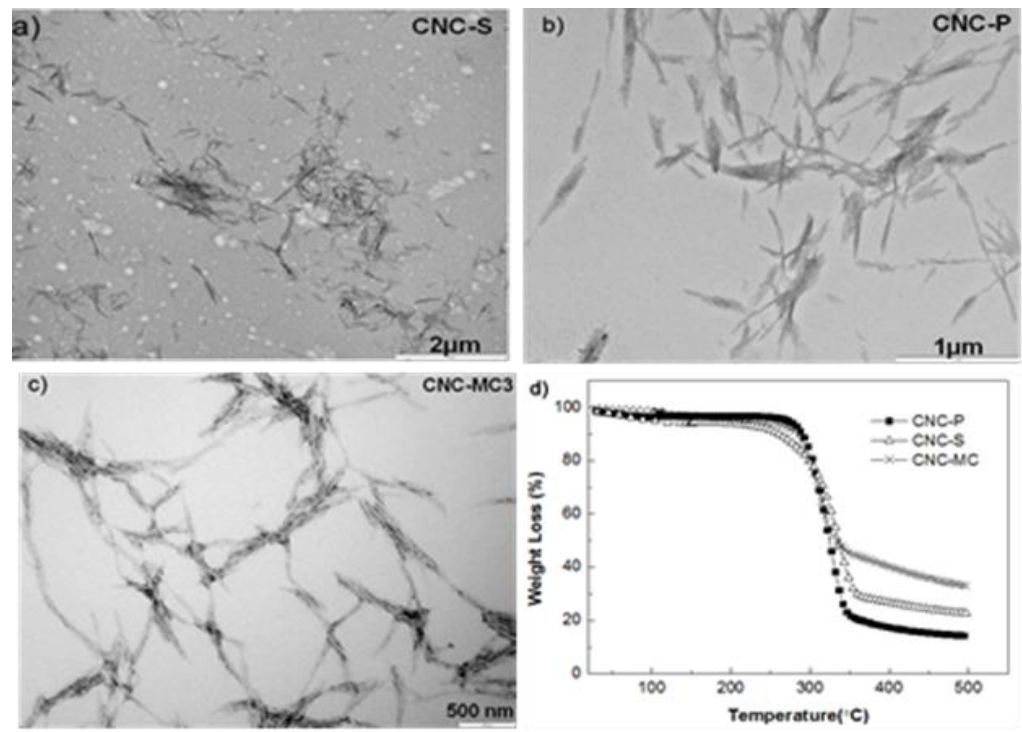

Figure 1. TEM images of CNCs produced from acid hydrolysis; a) CNC-S, b) CNC-P, c) HEBM method (CNC$\mathrm{MC}$ ) and d) their corresponding TGA thermograms

On the other hand, CNC-P and CNC-MC isolated from phosphoric acid hydrolysis and HEBM methods both clearly demonstrated a better thermal stability than CNC-S. Possibly phosphate group $\left(\left(\mathrm{PO}_{4}\right)^{3-}\right)$ attached on the surface of CNC-P is also able to assist with aqueous colloidal stability, but in this case without affecting the thermal behaviour of CNC [15]. The CNC-MC nanocellulose sample was successfully produced in a green and clean process (without the use of any acids or oxidising agents), and this approach also appears to have contributed to better thermal stability. Importantly, both of these strategies have shifted the onset degradation temperatures well above the typical melt compounding or reactive extrusion temperature window commonly employed for TPU processing with temperature of $180-230^{\circ} \mathrm{C}$, depending on the TPU grade and formulation.

Table 1. Dimensions and production yield of CNC isolated from the acid hydrolysis and HEBM methods

\begin{tabular}{lccccc}
\hline Sample & $\begin{array}{c}\text { Length } \\
(\mathbf{n m})\end{array}$ & $\begin{array}{c}\text { Diameter } \\
(\mathbf{n m})\end{array}$ & $\begin{array}{c}\text { Aspect } \\
\text { Ratio }\end{array}$ & $\begin{array}{c}\text { Yield } \\
(\boldsymbol{\%})\end{array}$ & $\begin{array}{c}\text { Onset Degradation Temperature } \\
\left(\mathbf{T}_{\text {onset }}\right)\left({ }^{\circ} \mathbf{C}\right)\end{array}$ \\
\hline CNC-S & $213 \pm 50$ & $16 \pm 3$ & 13 & 81 & 200 \\
CNC-P & $270 \pm 135$ & $26 \pm 13$ & 10 & 62 & 255 \\
CNC-MC & $424 \pm 90$ & $17 \pm 4$ & 25 & 76 & 258 \\
\hline
\end{tabular}

\section{Physical appearance of TPU nanocomposites}

The influence of different thermal stabilities and surface chemistry of CNC on processing can be clearly observed in Figure 2 from the physical appearance of compression moulded nanocomposite films produced via melt compounding and solvent casting. The TPU/CNC nanocomposite films produced via solvent casting retained the transparency of the host TPU at low 0.5-1 wt.\% loading levels for all types of CNCs, and at the higher 5 wt.\% loading the nanocomposites with CNC-S and CNC-MC showed just some feint discolouration. The solvent cast nanocomposites with CNC-P were able to retain the transparency of the host TPU even at $5 \mathrm{wt} . \%$. However, very obvious and commercially-unacceptable colour changes to darkening for nanocomposites obtained via meltcompounding can be seen from Figure 2, and the order of extent of discolouration is as follows: TPU control (MCTPU Control) < Nanocomposites using phosphoric acid hydrolysed CNCs (MC-TPU/CNC-P) $<$ Nanocomposites 
using micronised CNCs (TPU/CNC-MC) < Nanocomposites using conventional sulphuric acid hydrolysed CNCs MC-TPU/CNC-S.

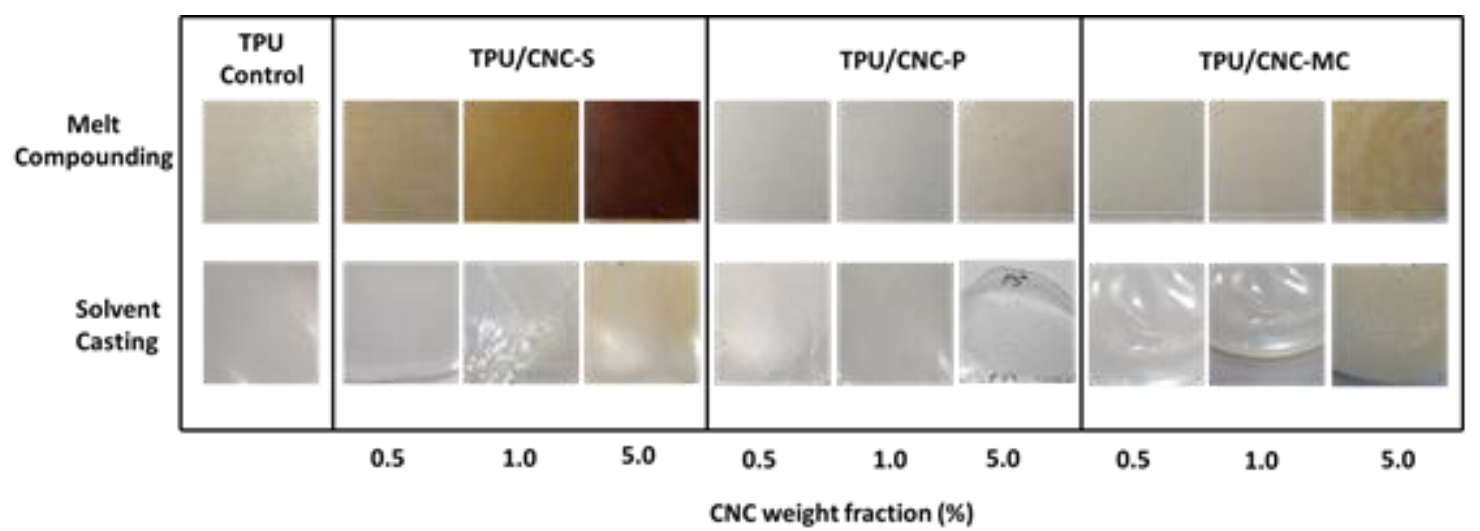

Figure 2. Photographs of TPU control and TPU/CNC nanocomposites processed via solvent casting (bottom) and melt compounding (top)

Even at 0.5 wt.\% of CNC-S loading, the light brown colour of nanocomposite films was noticeable. As the processing temperature employed in the extruder was about $225{ }^{\circ} \mathrm{C}$, the $\mathrm{CNC}$ isolated from sulphuric acid hydrolysis showed degradation behaviour and darkened. As reported previously, sulphate $\left(\mathrm{SO}_{4}\right)^{2-}$ groups, which are present on the surface of CNC might promote the dehydration reactions $[14,16,17]$. The onset degradation temperature of CNC-P and CNC-MC are 255 and $258^{\circ} \mathrm{C}$, respectively. However, the dispersibility of CNC-P where phosphate groups assist in achieving superior colloidal suspension stability is better than CNC-MC, which also gives rise to the discolouration of nanocomposites incorporating CNC-MC. This strongly suggests that this discolouration in melt compounded TPU nanocomposites is due to relative CNC thermal stability and degradation, which in-turn leads to the aggregation of the less thermally stable nanocellulose.

\section{Mechanical properties}

The reinforcement effect of the CNCs was investigated by measuring the tensile properties of the TPU control and its nanocomposites, at room temperature. Figure 3 shows the stress-strain curves of TPU control and nanocomposites produced via both processes and the values determined are summarized in Table 2. Obviously, no significant changes in tensile strength upon 0 to $300 \%$ of tensile strain were observed for melt compounded material, whereas solvent cast nanocomposites show the increase difference immediately after $50 \%$ of strain. The solvent cast TPU control obtained higher tensile strength than melt compounded materials. The reduction mostly contributed by transurethanisation reaction occurred due to the harsh environment in the extrusion process.

The tensile strength of TPU reinforced with CNC-S, CNC-P and CNC-MC shows 18\%, $16 \%$ and $14 \%$ of improvement respectively upon host polymer via melt compounding method. The increase was recorded at CNC loading of 0 to $1 \mathrm{wt} . \%$, as it reached $5 \mathrm{wt} . \%$ mechanical properties of the composites was declined. Regarding percolation model related to volume fraction of filler, the percolation threshold for CNC previously has been determined at $1-2$ volume $\%[18,19]$ for CNC to form network with polymer matrix which most probably linked by the hydrogen bonding. Thus, in this work, CNC loading at $5 \mathrm{wt}$ \% have been assumed ineffective as reinforcing element to the TPU matrix.

Moreover, elongation and stiffness at the optimum value of tensile strength were also unaffected indicating the softsegment domain of TPU was not disrupted by the cellulose addition. Furthermore, the reinforcement of CNC was also can be seen from the improvement in toughness and tear strength of TPU nanocomposites. These results indicate that CNCs able to work as an efficient stress transfer medium without disrupting the original function of the TPU microstructure (hard segment and soft segment). Indeed preventing the undesired stiffening with soft domain 


\section{REINFORCED THERMOPLASTIC POLYURETHANE}

was able to maintain the elongation of the TPU composites. The strength of the material fabricated via melt compounding is competent by comparing it with solvent casting process. This also proved that cellulose (CNC-P and CNC-MC) able to be processed with high processing temperature method.

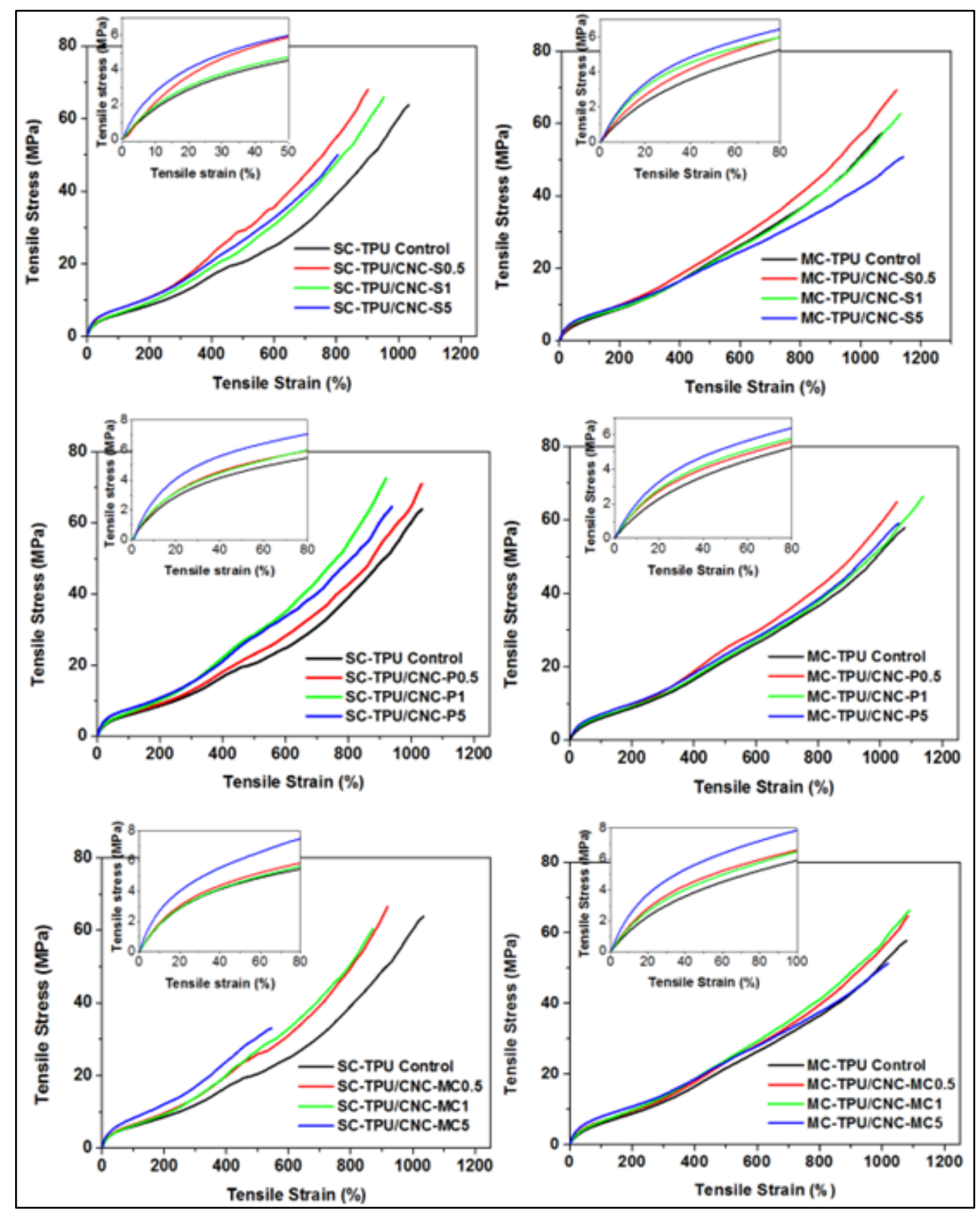

Figure 3. Stress-strain curves TPU nanocomposites fabricated via solvent casting (left column) and melt compounding (right column) 
Table 2. Summary of tensile properties of TPU nanocomposites processed via solvent cast (SC) and melt compounding (MC) method.

\begin{tabular}{|c|c|c|c|c|c|c|}
\hline Sample & & $\begin{array}{l}\text { Tensile } \\
\text { Stress } \\
(\mathrm{MPa}) \\
\end{array}$ & $\begin{array}{c}\text { Tensile } \\
\text { Strain at } \\
\text { Break }(\%) \\
\end{array}$ & $\begin{array}{l}\text { Modulus } \\
\text { (MPa) }\end{array}$ & $\begin{array}{c}\text { Toughness } \\
\text { (MPa) }\end{array}$ & $\begin{array}{c}\text { Tear } \\
\text { Strength } \\
(\mathrm{N} / \mathrm{mm}) \\
\end{array}$ \\
\hline \multirow{2}{*}{ TPU Control } & $\mathrm{SC}$ & $64.7 \pm 1$ & $954.6 \pm 33$ & $13.6 \pm 1$ & $258.9 \pm 7$ & $69.4 \pm 15$ \\
\hline & $\mathrm{MC}$ & $57.7 \pm 3$ & $1041.3 \pm 39$ & $11.3 \pm 1$ & $261.5 \pm 18$ & $119.9 \pm 4$ \\
\hline \multirow{2}{*}{$\begin{array}{l}\text { TPU/CNC- } \\
\text { S0.5 }\end{array}$} & $\mathrm{SC}$ & $67.1 \pm 8$ & $925.7 \pm 27$ & $17.4 \pm 3$ & $255.1 \pm 35$ & $88.6 \pm 8$ \\
\hline & MC & $67.9 \pm 3$ & $1115.7 \pm 29$ & $14.3 \pm 1$ & $319.3 \pm 21$ & $118.7 \pm 4$ \\
\hline \multirow{2}{*}{$\begin{array}{l}\text { TPU/CNC- } \\
\text { S1.0 }\end{array}$} & $\mathrm{SC}$ & $65.8 \pm 3$ & $964.6 \pm 35$ & $16.5 \pm 3$ & $261.9 \pm 14$ & $96.8 \pm 5$ \\
\hline & MC & $62.1 \pm 2$ & $1115.4 \pm 26$ & $15.0 \pm 1$ & $295.8 \pm 12$ & $123.2 \pm 1$ \\
\hline \multirow{2}{*}{$\begin{array}{l}\text { TPU/CNC- } \\
\text { S5.0 }\end{array}$} & $\mathrm{SC}$ & $49.4 \pm 4$ & $809.2 \pm 49$ & $21.6 \pm 4$ & $183.9 \pm 17$ & $73.7 \pm 11$ \\
\hline & $\mathrm{MC}$ & $51.3 \pm 1$ & $1137.5 \pm 19$ & $17.2 \pm 1$ & $281.6 \pm 9$ & $129.1 \pm 4$ \\
\hline \multirow{2}{*}{$\begin{array}{l}\text { TPU/CNC- } \\
\text { P0.5 }\end{array}$} & $\mathrm{SC}$ & $66.0 \pm 7$ & $994.8 \pm 55$ & $11.3 \pm 4$ & $256.2 \pm 39$ & $70.5 \pm 27$ \\
\hline & $\mathrm{MC}$ & $65.9 \pm 2$ & $1062.4 \pm 24$ & $13.5 \pm 1$ & $296.9 \pm 13$ & $121.7 \pm 5$ \\
\hline \multirow{2}{*}{$\begin{array}{l}\text { TPU/CNC- } \\
\text { P1.0 }\end{array}$} & $\mathrm{SC}$ & $66.2 \pm 6$ & $924.1 \pm 21$ & $14.0 \pm 1$ & $243.4 \pm 20$ & $88.6 \pm 3$ \\
\hline & $\mathrm{MC}$ & $66.8 \pm 1$ & $1108.8 \pm 29$ & $14.0 \pm 1$ & $295.8 \pm 12$ & $120.9 \pm 2$ \\
\hline \multirow{2}{*}{$\begin{array}{l}\text { TPU/CNC- } \\
\text { P5.0 }\end{array}$} & $\mathrm{SC}$ & $64.5 \pm 7$ & $950.8 \pm 62$ & $20.7 \pm 2$ & $271.2 \pm 40$ & $78.9 \pm 16$ \\
\hline & $\mathrm{MC}$ & $59.9 \pm 2$ & $1063.6 \pm 25$ & $16.2 \pm 1$ & $280.8 \pm 8$ & $123.5 \pm 7$ \\
\hline \multirow{2}{*}{$\begin{array}{l}\text { TPU/CNC- } \\
\text { MC } 0.5\end{array}$} & $\mathrm{SC}$ & $66.9 \pm 8$ & $956.0 \pm 46$ & $14.9 \pm 2$ & $256.3 \pm 33$ & $85.7 \pm 16$ \\
\hline & $\mathrm{MC}$ & $64.0 \pm 2$ & $1062.6 \pm 30$ & $12.6 \pm 1$ & $290.2 \pm 15$ & $113.1 \pm 6$ \\
\hline \multirow{2}{*}{$\begin{array}{l}\text { TPU/CNC- } \\
\text { MC1.0 }\end{array}$} & $\mathrm{SC}$ & $60.4 \pm 4$ & $822.4 \pm 70$ & $14.6 \pm 2$ & $210.3 \pm 24$ & $81.6 \pm 21$ \\
\hline & MC & $65.6 \pm 2$ & $1084.7 \pm 5$ & $12.4 \pm 1$ & $305.9 \pm 7$ & $125.2 \pm 7$ \\
\hline \multirow{2}{*}{$\begin{array}{l}\text { TPU/CNC- } \\
\text { MC5.0 }\end{array}$} & $\mathrm{SC}$ & $33.2 \pm 3$ & $583.7 \pm 75$ & $22.4 \pm 4$ & $103.3 \pm 19$ & $83.1 \pm 12$ \\
\hline & MC & $51.2 \pm 1$ & $1005.6 \pm 20$ & $21.1 \pm 1$ & $247.2 \pm 10$ & $126.6 \pm 4$ \\
\hline
\end{tabular}

\section{Conclusion}

Three types of CNCs isolated via sulphuric acid hydrolysis (CNC-S), phosphoric acid hydrolysis (CNC-P) and mechanical milling method (CNC-MC) were successfully incorporated into TPU via melt compounding method. These nanocomposites were compared with that processed via conventional solvent casting method. The thermally stable CNCs (CNC-P and CNC-MC) have demonstrated the melt process ability with polyether based thermoplastic polyurethane (TPU) without affecting the optical transparency, whereas, CNC-S has shown the degradation behavior. Remarkable reinforcement effect has been observed for nanocomposites with all the three CNCs, in terms of improvement in tensile strength and toughness without affecting elongation. It can be summarized that CNC isolated via mild acid hydrolysis and an optimized mechanical milling methods, can be easily processed via large scale melt-processing techniques for reinforcing thermoplastic polyurethanes at 0.5-1 wt. \% without affecting their physical appearance and elastic properties.

\section{Acknowledgement}

The authors gratefully acknowledge the facilities as well as the scientific and technical assistance of the Centre for Microscopy and Microanalysis, University of Queensland. Khairatun Najwa also thanks to the Ministry of Education Malaysia and Universiti Malaysia Pahang for the financial support. 


\section{Khairatun Najwa et al: CELLULOSE NANOCRYSTALS WITH ENHANCED THERMAL STABILITY}

REINFORCED THERMOPLASTIC POLYURETHANE

\section{References}

1. Barick, A. K., Jung, J. Y., Choi, M. C. and Chang, Y. W. (2013). Thermoplastic vulcanizate nanocomposites based on thermoplastic polyurethane and millable polyurethane blends reinforced with organoclay prepared by melt intercalation technique: Optimization of processing parameters via statistical methods. Journal of Applied Polymer Science, 129 (3): 1405 - 1416.

2. Koerner H., Liu, W., Alexander, M., Mirau, P., Dowty, H. and Vaia, R. A. (2005). Deformation-morphology correlations in electrically conductive carbon nanotube - thermoplastic polyurethane nanocomposites. Polymer, 46 (12): 4405 - 4420.

3. Kotal, M., Kuila, T., Srivastava, S. and Bhowmick, A. (2009). Synthesis and characterization of polyurethane/Mg-Al layered double hydroxide nanocomposites. Journal of Applied Polymer Science, 114 (5): $2691-2699$.

4. Barick A. and Tripathy D. (2010). Thermal and dynamic mechanical characterization of thermoplastic polyurethane/organoclay nanocomposites prepared by melt compounding. Materials Science and Engineering: A, 527(3): $812-823$.

5. Liu, H., Liu, D., Yao, F. and Wu, Q. (2010). Fabrication and properties of transparent polymethylmethacrylate/cellulose nanocrystals composites. Bioresource Technology, 101(14): 5685 -5692.

6. Pei, A., Malho, J. M., Ruokolainen, J., Zhou, Q. and Berglund, L. A. (2011). Strong nanocomposite reinforcement effects in polyurethane elastomer with low volume fraction of cellulose nanocrystals. Macromolecules, 44 (11): 4422 - 4427.

7. Jyoti, J., Basu, S., Singh, B. P. and Dhakate, S., (2015). Superior mechanical and electrical properties of multiwall carbon nanotube reinforced acrylonitrile butadiene styrene high performance composites. Composites Part B: Engineering, 83: 58 - 65.

8. Oksman, K., Mathew, A., Bondeson, D. and Kvien, I. (2006). Manufacturing process of cellulose whiskers/polylactic acid nanocomposites. Composites Science and Technology, 66 (15): 2776 - 2784.

9. Ben Azouz, K., Ramires, E. C., Van den Fonteyne, W., El Kissi, N. and Dufresne, A. (2011). Simple method for the melt extrusion of a cellulose nanocrystal reinforced hydrophobic polymer. ACS Macro Letters, 1(1): 236 -240 .

10. Capadona, J. R., Van Den Berg, O., Capadona, L. A., Schroeter, M., Rowan, S. J. and Tyler, D. J. (2007). A versatile approach for the processing of polymer nanocomposites with self-assembled nanofibre templates. Nature Nanotechnology, 2(12): 765 - 769.

11. Camarero Espinosa, S., Kuhnt, T., Foster, E. J. and Weder, C. (2013). Isolation of thermally stable cellulose nanocrystals by phosphoric acid hydrolysis. Biomacromolecules, 14(4): 1223 - 1230.

12. Amin, K. N. M., Annamalai, P. K., Morrow, I. C. and Martin, D. (2015). Production of cellulose nanocrystals via a scalable mechanical method. RSC Advances, 5(70): 57133 - 57140.

13. Wang, N., Ding, E. Y., \& Cheng, R. S. (2007). Thermal degradation behaviors of spherical cellulose nanocrystals with sulfate groups. Polymer, 48(12): 3486 - 3493.

14. Roman, M. and Winter, W. T. (2004). Effect of sulfate groups from sulfuric acid hydrolysis on the thermal degradation behavior of bacterial cellulose. Biomacromolecules, 5(5):1671 - 1677.

15. Salajkova, M. (2013). Wood nanocellulose materials and effects from surface modification of nanoparticles. Thesis Doctor of Philosophy. KTH Royal Institute of Technology.

16. Wang N., Ding, E. and Cheng, R. (2007). Thermal degradation behaviors of spherical cellulose nanocrystals with sulfate groups. Polymer, 48(12): 3486 - 3493.

17. Kargarzadeh, H., Ahmad, I., Abdullah, I., Dufresne, A., Zainudin, S. and Sheltami, R. (2012). Effects of hydrolysis conditions on the morphology, crystallinity, and thermal stability of cellulose nanocrystals extracted from kenaf bast fibers. Cellulose, 19(3): 855 - 866.

18. Favier, V., Chanzy, H. and Cavaille, J. Y. (1995). Polymer nanocomposites reinforced by cellulose whiskers. Macromolecules, 28(18): 6365 - 6367.

19. Dufresne, A., Cavaillé, J. Y. and Helbert, W. (1997). Thermoplastic nanocomposites filled with wheat straw cellulose whiskers. Part II: Effect of processing and modeling. Polymer Composites, 18(2): 198 -210. 